SHS Web of Conferences 2, 00034 (2012)

DOI: $10.1051 /$ shsconf/20120200034

(C) Owned by the authors, published by EDP Sciences, 2012

\title{
Awareness of doctors of health care and possible therapy methods for alcohol and drug dependant patients in Latvia
}

\author{
V. Sudraba ${ }^{1}$, E. Rancans ${ }^{2}$ and V. Dave ${ }^{1}$ \\ ${ }^{1}$ Riga Centre of Psychiatry and Addiction Disorders, Latvia \\ ${ }^{2}$ Rigga Stradinsš University, Latvia
}

\begin{abstract}
Aim is to investigate the knowledge of Latvian doctors about addiction treatment and healthcare possibilities in Latvia, to compare which methods are the best known to physicians, and which are offered to addicted patients. Work material and methods. Questionnaire was developed by researchers themselves, it contains 14 questions (about demographical data, treatment methods and their application). 250 questionnaires were distributed, $158(63,2 \%)$ were received. Results. Average age of participants 43.7 years. $31,0 \%$ of respondents are psychiatrists, $13,3 \%$ - addiction specialists, $34,8 \%$ - other specialists (general practitioners, internists, health care doctors, neurologists and others), 12,0\% - psychotherapists, $4,4 \%$ - surgeons, $1,9 \%$ - dentists and 1,9\% - paediatricians. The best known were detoxification $(98,2 \%)$ and suggestion (892\%) methods. The least known methods for drug addicts were substitution therapy $(73,4 \%)$ and rehabilitation communities $(73,4 \%)$. The most recommended treatment method was Minnesota programme - $108(68,4 \%)$ and detoxification 99 (62,7\%), the least recommended - substitution therapy $-29(18,5 \%)$. Conclusions. $17,1 \%$ of respondents do not meet patients with addiction problems, but $20,3 \%$ of respondents don't recommend any of treatment methods. Although 73\%-98\% of respondents have information about treatment methods, only $18 \%-68 \%$ of respondents offer them.
\end{abstract}

Key words: dependence, detoxification, suggestive methods, psychotherapy, self-help groups

Alcohol is the third most important risk factor of health in Europe among 26 risk factors (WHO, 2002). More than one death out of every 10 death cases in Eastern Europe occurs due to alcohol abuse (WHO, 2009). Alcohol consumption per capita is the main indicator of alcohol monitoring, and also one of 88 public health indicators brought up by European Commision. It is included in the list of public health indicators as number 46 along with the indicator - death caused by alcohol and drug use, marked 16 and 15 accordingly (Kilpelainen et al., 2008). When analyzing measurements of alcohol consumption indicators it is possible to predict the distribution of consequences associated with alcohol use, as well as to choose effective, evidence based interventions that can reduce negative effects of alcohol abuse (VEC, 2010).

Registered consumption of absolute alcohol per capita in Latvia in 2009 was 6.1 litres. For the first time in the period of the last seven years this parameter has significantly reduced - by about 3.8 litres comparing to 2008. Nevertheless these data can be compared only partly, because since 2009 unregistered consumption of alcohol that includes illegally brought, home-made alcohol, as well as alcohol stolen from factories, brought by tourists and etcl., is not any longer included in the consumption of absolute alcohol as it was previously (VEC, 2010).

Excessive use of alcohol affects a person individually as well as the environment and society in general. There are negative effects due to chronic use of alcohol and problems caused by short-term alcohol use. Death due to acute use of alcohol is among deaths due to, external factors as stated by WHO and they are: death from intoxication with alcohol and surrogates, mortality from traffic accidents, accidents at workplace, drowning due to alcohol use, suicides, murder, violence at home and family, etc. These consequences are related mostly to young people contributing to notable social expenses and

This is an Open Access article distributed under the terms of the Creative Commons Attribution License 2.0, which permits unrestricted use, distribution, and reproduction in any medium, provided the original work is properly cited. 


\title{
SHS Web of Conferences
}

high loss of years of life (WHO, 2000). Very important indicators that show consequences of long term alcohol use are illnesses of liver (cirrhosis) and mortality due to these illnesses, as well as mental health disorders related to alcohol abuse (alcohol intoxication, addiction and alcohol psychosis). Use of alcohol increases morbidity and mortality from other disorders that are directly related to alcohol use - alcohol pancreatitis, hepatitis, alcohol epilepsy and polyneuropathia, alcohol myelopathia, etc. (VEC, 2010).

The substance abuse causes negative consequences in patient's health: induce problems in patient's thinking process, behaviour, emotional lability, and sleep disturbances, problems in digestive and cardiovascular (Osis, 2006; Фридман et al., 2000).

Drug use is one of the main causes of mortality for young people. According to the data collected by Latvian Centre of Infectology there were 4614 cases (204 on 100.000) of HIV infections registered in 2009. In the stage of AIDS there were 826 persons registered. During the above mentioned period of time there were 859 death cases registered in persons who had been living with HIV. HIV prevalence in Latvia is high when comparing HIV prevalence in Europe. Drug abuse increases the risk of concomitant virus hepatitis $\mathrm{B}$, hepatitis $\mathrm{C}$, tuberculosis, different mental health disorders. Overdosing of drugs may lead to death (VEC, EMCDAA, 2010).

Addiction specialists, psychiatrists, general practitioners and other specialists have patients with health problems, caused by alcohol and drug addiction. It is important, that patient with substance use disorders, comes to addiction specialist in time. On one hand, the problem is that very often other specialists help the patient to lessen the symptoms of abuse at once, and don't ask addiction specialist to consult the patient. On the other hand, the problem is that patients themselves don't assume, that their addiction is a disease, and therefore don't seek professional help, but go to "extrasenses", "healers", "wizards", etc.

Several treatment methods exist in Latvia. Those are detoxification, relapse prevention methods (applying suggestive therapy and sensibilizing drugs - like "ampoule", "coding", "torpedo") and psychotherapeutically oriented methods (motivation, Minnesota model program, rehabilitation communities for drug addicts).

Research on the awareness of doctors about available treatment methods for patients with addiction disorders has not been done in Latvia before.

\begin{abstract}
Aim
To investigate the knowledge of Latvian doctors about addiction treatment and healthcare possibilities in Latvia, to compare which methods are the best known to physicians, and which are offered to addicted patients.
\end{abstract}

\section{Work material and methods}

In the investigation selected respondents were enquired. Questionnaire containing 14 questions (about demographical data, treatment methods and their application) was used. It was developed by researchers themselves. Primary data processing was performed and questionnaires were analyzed by means of SPSS 14.0 program. Analysis was performed using methods of statistical data analysis (descriptive method).

\section{Results}

250 questionnaires were distributed, $158(63,2 \%)$ were received. Age of participants was from 27 to 74 years, average age -43.7 years, that means they are specialists with enough experience of life and professionallye. Percentage of respondents between different specialities is showed in Figure 1. $31,0 \%$ of respondents are psychiatrists, $13,3 \%$ - addiction specialists, $34,8 \%$ - other specialists (general 
Int. Conf. SOCIETY. HEALTH. WELFARE; Congr. of Rehabilitation Doctors of Latvia

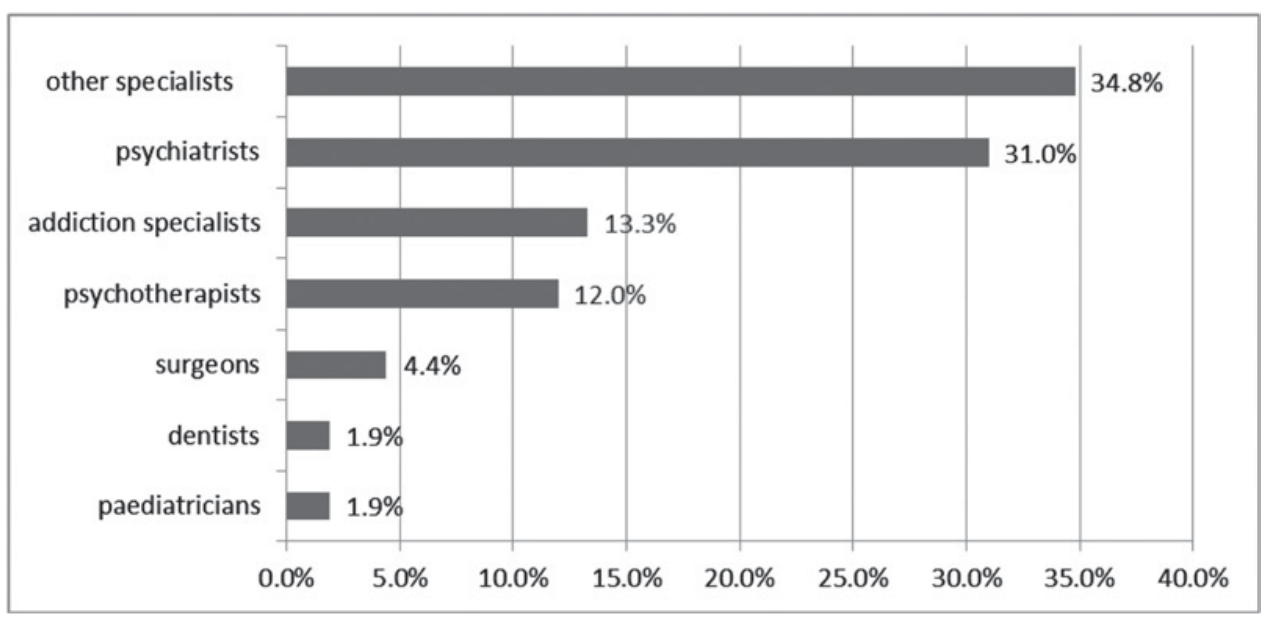

Figure 1. Percentage of respondents in different specialities.

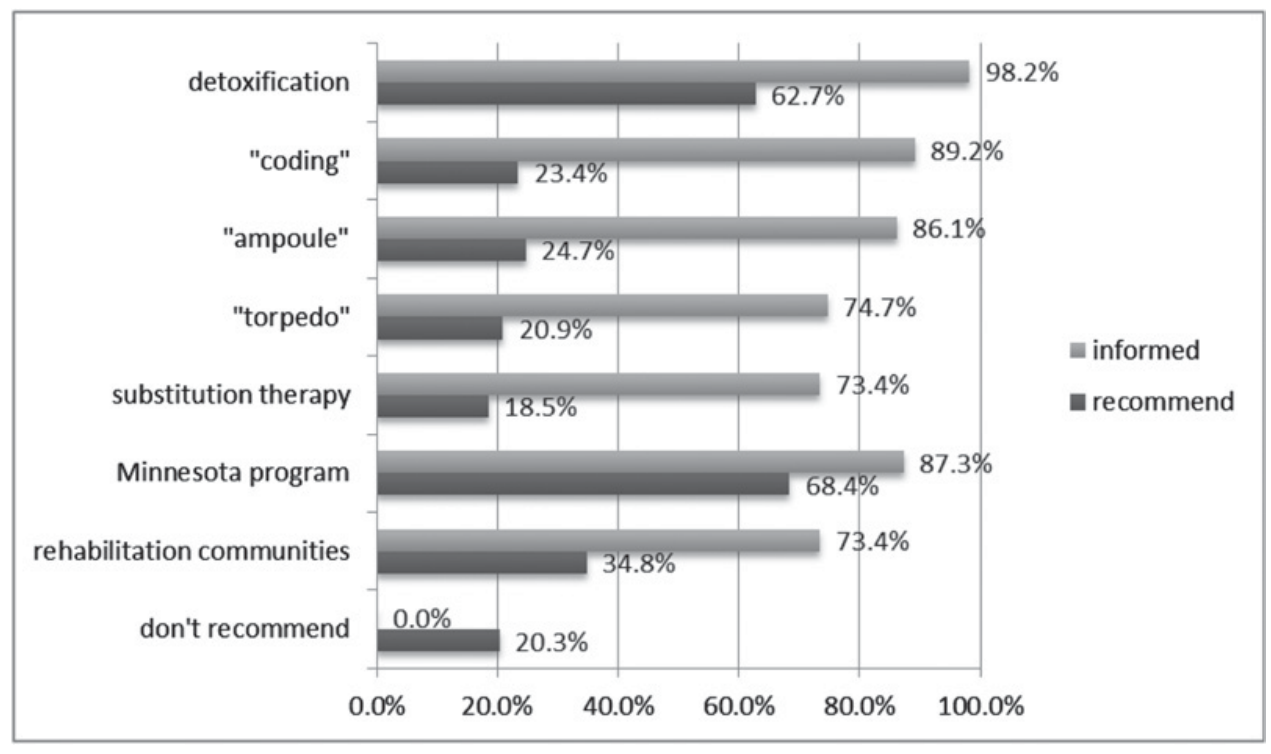

Figure 2. Awareness of respondents about treatment possibilities and recommending the possibilities to patients.

practitioners, internists, health care doctors, neurologists and others), 12,0\% - psychotherapists, 4,4\% surgeons, $1,9 \%$ - dentists and $1,9 \%$ - paediatricians.

Professional workplace location - the biggest part of respondents work in Riga and district of Riga $(60,8 \%), 131(82,9 \%)$ respondents see several alcohol dependant patients every day. $85(53,8 \%)$ respondents - drug dependant ones, $27(17,1 \%)$ specialists do not have. All the respondents were informed about the methods of addiction treatment (Figure 2).

The best known were detoxification $(98,2 \%)$ and suggestion $(89,2 \%)$ methods. The least known methods for drug addicts were substitution therapy $(73,4 \%)$ and rehabilitation communities $(73,4 \%)$. $138(87,3 \%)$ respondents were informed about psychotherapeutic treatment in Minnesota programme. The most recommended treatment method was Minnesota programme - $108(68,4 \%)$ and detoxification $99(62,7 \%)$, the least recommended - substitution therapy - $29(18,5 \%)$. When asked which methods 


\section{SHS Web of Conferences}

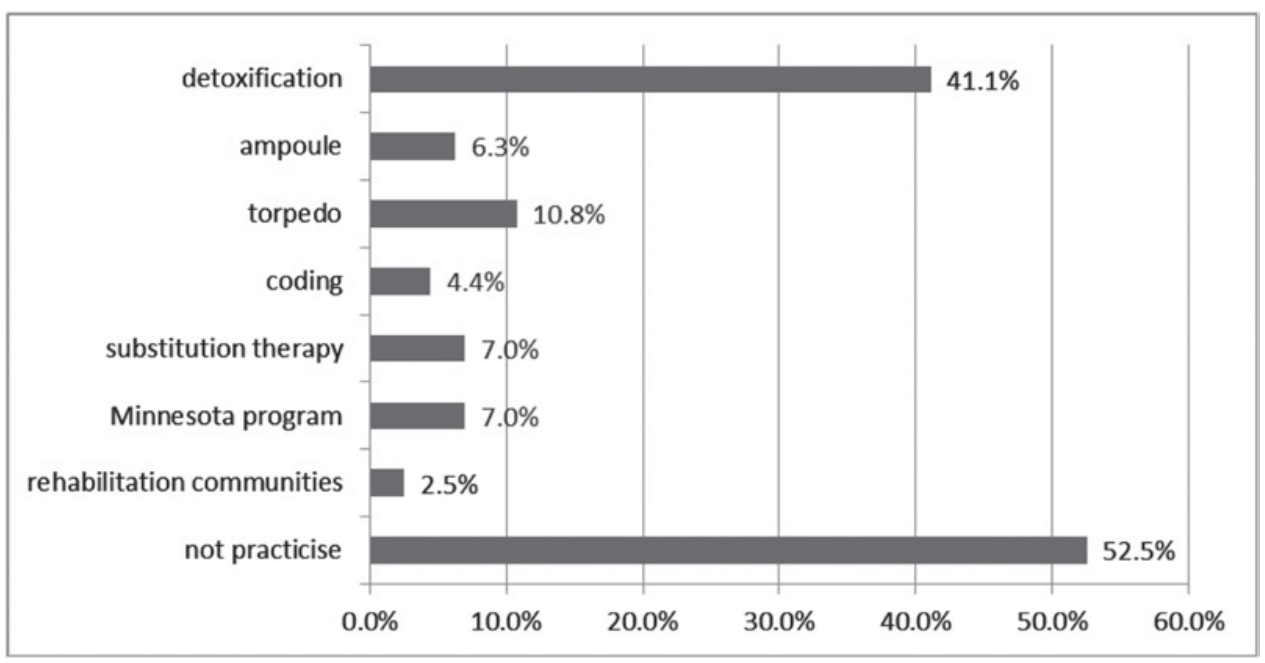

Figure 3. Used methods of dependence treatment by respondents in their practice.

of dependence treatment doctors use in their practice, $65(41,1 \%)$ answered they use detoxification, suggestive methods use $21,5 \%$, substitution therapy and Minnesota program - by $7,0 \%$, rehabilitation communities $-2,5 \%$, but $83(52,5 \%)$ doctors do not practice any dependence treatment method (Figure 3).

$57,7 \%$ of respondents were informed about AA (Alcoholics Anonymous) self-help groups at their workplace region, 22,2\% - were informed about NA (Narcotics Anonymous), 13,3\% - about GA (Gamblers Anonymous) groups, 38,6\% of respondents did not know if such groups do exist, but 6,3\% think that there are no such groups at their workplace region, also specialists working in Riga and Riga region. Nevertheless $116(73,4 \%)$ doctors recommend patients to go to self-help groups.

\section{Conclusions}

1. The inquired doctors in Latvia are well informed about dependence treatment methods. 2. Most of respondents recommend Minnesota program for patients with substance abuse and gambling. It can be seen, that doctors understand addictions as bio-psycho-social diseases. 3. Doctors recommend detoxification most frequently, probably, because they use this method in their practice by themselves. 4 . Substitution therapy was offered least frequently by other specialists, as it is a specific method. 5. 20,3\% of doctors don't offer any method of dependence treatment help to dependant patients. $6.17,1 \%$ of respondents do not meet patients with addiction problems, but 20,3\% of respondents don't recommend any of treatment methods. 7. Although $73 \%-98 \%$ of respondents have information about treatment methods, only $18 \%-68 \%$ of respondents offer them. 8. Although 38,6\% of respondents don't know, if there is a self-help group in their workplace region, and 6,3\% think that there is none, nevertheless $73,4 \%$ of respondents offer to attend a self-help group.

It is necessary to continue the research, inquiring greater number of psychiatrists, addiction specialists, general practitioners and other specialities, who get in touch with dependant patients. It is important to determine in details the awareness of doctors of health care and possible therapy methods for dependant patients in Latvia. Aim is to improve the treatment for our patients by improving physician's awareness.

It is important to investigate which speciality doctors are less informed about the treatment possibilities and according to the gained data develop educational programs addressing explanation 
Int. Conf. SOCIETY. HEALTH. WELFARE; Congr. of Rehabilitation Doctors of Latvia

that addiction disorders are bio-psycho-social diseases, as well as to inform them about the possible treatment possibilities.

\section{References}

[1] Kilpelainen, K., Aromaa, A., ECHIM Core Group (eds.) (2008) ECHIM European health indicators: Development and initial implementation. Final report of the ECHIM project, p.30-55. http: //www.echim.org/docs/ECHIM_final_report.pdf

[2] WHO (2000) International guide for monitoring alcohol consumption and related harm. Geneva. http://whqlibdoc.who.int/hq/2000/WHO_MSD_MSB_00.4.pdf

[3] WHO (2002) The World health report: Reducing risk, promoting healthy life. Geneva. http://www.who.int/whr/2002/en/summary_riskfactors_chp4.pdf

[4] WHO (2009) Global health risk. Mortality and burden of disease attributable to selected major risks. Geneva. http://www.who.int/healthinfo/global_burden_disease/ GlobalHealthRisks_report_full.pdf

[5] Osis, G. (2006) Narkolog̣ijas vispārējās prakses ārstiem. [Narcology for general practitioners]. Rīga: SIA “TRIO-J”.

[6] Valsts Ekonomikas centrs (VEC) (2010) Atkarību izraisošo vielu lietošanas izplatība un sekas Latvijā 2009. gadā. [The Prevelance and Consequences Dependency Inducing Substancies in Latvia]. Tematisks ziņojums. 18. izdevums. Rīga. http://vec.gov.lv/uploads/files/ 4d36ce646127b.pdf

[7] VEC, EMCDAA (2010) Situācija narkomānijas problēmas jomā Latvijā 2009.gadā. [The state of the drugs problem in Latvia]. Nacionālais ziņojums. Reitox. http://vec.gov.lv/uploads/ files/4d53ac062d93e.pdf

[8] Фридман, Л.С., Флеминг, Н.Ф., Робертс, Д.Х, Хайман, С.Е. (2000) Наркология. [Narcology]. Мockва: “Издательство БИНОМ” - “Невский Диалект”. 